\title{
The Evaluation of the Antibacterial and Antioxidant Activity of Tarragon (Artemisia dracunculus L.) Essential Oil and Its Chemical Composition
}

\author{
Reza Sharafati Chaleshtori ${ }^{1, *}$, Noordahr Rokni ${ }^{2}$, Vadood Razavilar ${ }^{3}$, Mahmoud Rafieian \\ Kopaei $^{4}$ \\ ${ }^{1}$ Department of Food Hygiene, Faculty of Specialized Veterinary Sciences, Science and Research Branch, Islamic Azad University, Tehran, IR Iran \\ ${ }^{2}$ Faculty of Veterinary Medicine, Tehran University of Medical Sciences, Tehran, IR Iran \\ ${ }^{3}$ Department of food hygiene, Science and Research Branch, Islamic Azad University, Tehran, IR Iran \\ ${ }^{4}$ Medical Plants Research Center, Shahre-Kord University of Medical Sciences, Shahre-Kord, IR Iran \\ ${ }^{*}$ Corresponding author: Reza Sharafati Chaleshtori, Department of Food Hygiene, Faculty of Specialized Veterinary Sciences, Science and Research Branch, Islamic Azad University, \\ Tehran, IR Iran. Tel:+98-3812243085, Fax:+98-3813334911, E-mail: sharafati33@yahoo.com.
}

Received: August 23, 2012; Revised: November 30, 2012; Accepted: December 15, 2012

Background: Food born pathogenic bacteria are the most important agents of infections in humans, and food spoilage also results in economic losses in food industry.

Objectives: The aim of this study was the evaluation of chemical components, total phenolic content, antioxidant and antibacterial activities of Artemisia dracunculus essential oil.

Materials and Methods: The essential oil of Tarragon was analyzed by gas chromatography-flame ionization detector (GC-FID) and gas chromatography/mass spectrometry (GC-MS). The antioxidant activity and total phenolic content were evaluated by bleaching of $\beta$-carotene and folin ciocalteu methods, respectively. The antibacterial effect of the essential oil was inspected on seven Gram-positive and negative bacteria using the microdilution method.

Results: A total of 19 compounds were identified by GC-FID and GC-MS. The main compounds were methyl chavicol (84.83\%), trans-ocimene (3.86\%), z- - - -ocimene (3.42\%), limonene (1.79\%) and $\alpha$-pinene (0.57\%). Total phenols were $10.16 \pm 0.08 \mathrm{mg} / \mathrm{g}$ Gallic acid equivalent. The essential oil showed good antioxidant activity in bleaching of $\beta$-carotene method (50 $\pm 1.63 \%)$. The minimum inhibitory concentrations (MIC) and minimum bactericidal concentrations (MBC) for essential oil ranged between 3.8 to $250 \mathrm{mg} / \mathrm{mL}$, respectively.

Conclusions: The essential oil of Tarragon might be replaced by synthetic antioxidant and preservatives in food industry.

Keywords: Gas Chromatography-Mass Spectrometry; Artemisia; Essential Oil; Food Preservatives; Antioxidants

\section{Background}

Nowadays, academic researchers and food industries search for alternative sources of chemical preservatives as protection agents against lipid oxidation and growth of pathogenic bacteria in food. Familiarly, eugenol, limonene, carvacrol and geraniol have been identified as natural food preservatives with no mutagenic effects (1). However, the utilization of chemical antioxidants with high activity, such as tertiary butyl hydroquinone (TBHQ), can threaten the human health (2). The essential oils of spices and medicinal plants containing phenolic compounds have antioxidant and antibacterial properties that have been widely used in pharmaceutical, sanitary, cosmetic, agricultural and food industries around the world $(1,3)$.

The presence of bioactive substances in medicinal plants may react with microorganisms and restrain microbial growth. Therefore, their extracts and essential oils are regarded as good candidates for replacing syn- thetic preservatives. Previous works have demonstrated the antioxidant and antibacterial activities of essential oils on food spoilage and pathogen bacteria (4).

The genus Artemisia is a small shrub from the Asteraceae family. In Iran, Tarragon (Artemisia dracunculus L.) is called "Tarkhon" and as a traditional medicinal plant is used for the treatment of stomach pains, pyrexia, diabetes and parasitic or bacterial infections. The fresh and dried leaves are commonly used in salads, soups and barbecues. Furthermore, its essential oil is used as an aromatic and flavoring agent in food industry $(2,5)$. In a study conducted in Turkey, using the disc diffusion method, it has been shown that the essential oil of A.dracunculus has antibacterial effects and antifungal activities on eleven pathogenic fungi (6).

\section{Objectives}

The aim of this study was to evaluate the antioxidant

Implication for health policy/practice/research/medical education:

The essence of Tarragon can be used as a natural antibacterial and antioxidant agent in food industry.

Copyright @ 2013, Ahvaz JundishapurUniversity of Medical Sciences; Published by Kowsar Corp. This is an open-access article distributed under the terms of the Creative Commons Attribution License, which permits unrestricted use, distribution, and reproduction in any medium, provided the original work is properly cited. 
and antibacterial activities of Tarragon (A. dracunculus L.) essential oil as well as its chemical composition.

\section{Materials and Methods}

\subsection{Preparation of the Essential oil}

Samples of Tarragon (A. dracunculus) were collected in November 2011 from Charmahal va Bakhtiari Province of Iran. Voucher specimens of the collected Tarragon were confirmed and deposited at the herbarium of the Medical Plants Research Center of Shahrekord University of Medical Sciences, Iran (No. 235). The dried plants (100 g) were hydro-distilled for 3 hours using a Clevenger type apparatus. The essential oil was then dehydrated over anhydrous sodium sulphate and kept in sealed vials at $4^{\circ} \mathrm{C}$ (7).

\subsection{Essential Oil Analysis by Gas Chromatography and Gas Chromatography-Mass Spectrometry (GC-MS)}

The essential oil from Tarragon was analyzed using a Younglin Acme 6000 gas chromatography-flame ionization detector (GC-FID) with a HP-5MS capillary column (30 $\mathrm{m} \times 0.25 \mathrm{~mm}$, film thickness $0.25 \mu \mathrm{m}$ ). Helium was used as the carrier gas at a flow rate of $0.8 \mathrm{~mL} /$ minute. The essential oil was diluted in n-pentane $(1 / 1000, v / v)$ and $1.0 \mu \mathrm{L}$ was injected in the splitless mode. The primary oven temperature was maintained at $50^{\circ} \mathrm{C}$ for 5 minutes and then increased up to $240^{\circ} \mathrm{C}$ at a rate of $3^{\circ} \mathrm{C}$ /minute. Temperatures of injector and detector were $290^{\circ} \mathrm{C}$ and $300^{\circ} \mathrm{C}$, respectively. Percent of each compound was obtained from the comparison of the area under each curve of GC peaks with the total area under the curves in which correction factors weren't used. For the GC-MS analysis an Agilent 6890 GC system with a HP-5MS capillary column $(30 \mathrm{~m} \times 0.25 \mathrm{~mm}$, film thickness $0.25 \mu \mathrm{m})$ fitted with an Agilent HP- 5973 mass selective detector was used. The electron ionization (EI) system with ionization energy of $70 \mathrm{eV}$ and temperature of ion source $220^{\circ} \mathrm{C}$ was used for GC-MS detection. Other stages were under similar conditions as GC. Mass spectra were scanned between 50 and 550 a. m. u. range.

\subsection{Identification of Essential Oil Constituents}

The identification of the constituents of the essential oil was achieved by comparing their retention indices (determined with homologous series of n-alkanes C8-C20, under similar conditions) with data reported on authentic compounds in articles, references books as well as standard libraries (Wiley275.L and Wiley7n.L) (8).

\subsection{Total Phenolic Contents}

Total phenolic content was examined by Folin Ciocalteu method (9). The result was expressed as mg of Gallic Acid Equivalents/g of the essential oil (GAEs).

\subsection{Antioxidant Activity}

The total antioxidant capacity of $A$. dracunculus essential oil was assayed using $\beta$-carotene and linoleic acid with minor modification (10). A stock solution of $\beta$-carotene (0.5 $\mathrm{mg}$ ) was prepared in $1 \mathrm{~mL}$ of chloroform, linoleic acid ( 25 $\mu \mathrm{L})$, and Tween-40 (200 mg). Chloroform was completely evaporated using a vacuum evaporator at $50^{\circ} \mathrm{C}$ and 100 $\mathrm{mL}$ of oxygenated water (30 minutes $100 \mathrm{~mL} / \mathrm{minute}$ ) was added under vigorous shaking. From this emulsion, 2.5 $\mathrm{mL}$ aliquots were added to test tubes and $350 \mu \mathrm{L}$ of the essential oil prepared at $4 \mathrm{~g} / \mathrm{L}$ concentrations was added and incubated for 48 hours at room temperature. For the positive control, the same procedure was repeated with Butylated hydroxytoluene (BHT) and a blank (only $350 \mu \mathrm{L}$ ethanol). The absorbance of the solutions was measured at $490 \mathrm{~nm}$. Antioxidant activity of the essence was compared with those of the BHT and the blank.

\subsection{Test Organism and Antibacterial Assay}

Cultures of Staphylococcus aureus PTCC (Persian Type Culture Collection) 1189, Alcaligenes faecalis PTCC 1624, Providencia rettgeri PTCC 1512, Serratia marcescens PTCC 1621, Shigella dysenteriae PTCC 1188, Listeria monocytogenes PTCC 1163 and Klebsiella oxytoca 1402 were purchased from Iranian Research Organization for Science and Technology (IROST). The bacterial strain was inoculated in tryptic soy broth (TSB, Merck Ink, Darmstadt, Germany) at $37^{\circ} \mathrm{C}$ overnight, and 0.5 McFarland Standard was prepared with densities of $1.5 \times 108 \mathrm{cfu} / \mathrm{mL}$ in phosphate buffered saline (PBS) (11). The microtiter broth method in sterile 96-microwell plates was used for minimum inhibitory concentration (MIC) (12).

The essence obtained was dissolved in dimethyl sulfoxide (DMSO). Further $95 \mu \mathrm{L}$ Mueller Hinton broth (Merck Ink. Darmstadt, Germany) plus $5 \mu \mathrm{L}$ bacterial suspensions plus $100 \mu \mathrm{L}$ serial 2-fold dilution of essential oil (3.8-1000 $\mathrm{mg} / \mathrm{mL}$ ) were added in microwell and incubated at $37^{\circ} \mathrm{C}$ for 18 hours. Negative control was $195 \mu \mathrm{L}$ Mueller-Hinton broth plus $5 \mu \mathrm{L}$ bacterial suspensions and positive control was $95 \mu \mathrm{L}$ Mueller Hinton broth plus $5 \mu \mathrm{L}$ bacterial suspensions and $100 \mu \mathrm{L}$ of chloramphenicol (Sigma-Aldrich Corporation St. Louis, MO. USA) as a positive antimicrobial reference. Bacterial growth was measured by reading the optical density at $450 \mathrm{~nm}$ using an ELISA reader (State fax 2100, USA) at 0 and 18 hours post-inoculation. After 18 hours, the MIC value was determined from the first well, without turbidity. The contents of the wells with no growth were spread on Mueller Hinton agar (Merck Ink. Darmstadt, Germany) and incubated at $37^{\circ} \mathrm{C}$ for 24 hours. The minimum bactericidal concentration (MBC) was identified as the lowest concentration that did not allow bacterial growth. Each experiment was repeated in 
triplicates.

\section{Results}

Nineteen compounds were identified; the main constituents of the essential oil were methyl chavicol (84.83\%), trans-ocimene (3.86\%), z- $\beta$-ocimene (3.42\%), limonene $(1.79 \%)$ and $\alpha$-pinene (0.57\%). Majority of the compounds in the essential oil were monoterpene hydrocarbons (95.904\%) and the lowest levels were related to sesquiterpene hydrocarbons (0.46\%). The constituents of essential oil can be observed in Table 1 .

\begin{tabular}{|c|c|c|c|c|}
\hline Number & Retention Time & Kovats Indices & Name & Concentration, $\%$ \\
\hline $\mathbf{1}$ & 11.23 & 927 & $\alpha$-pinene & 0.57 \\
\hline 2 & 13.31 & 969 & $\beta$-pinene & 0.107 \\
\hline 3 & 14.14 & 986 & $\beta$-myrcene & 0.1 \\
\hline 4 & 16.06 & 1025 & Limonene & 1.79 \\
\hline 5 & 16.67 & 1037 & z- $\beta$-ocimene & 3.42 \\
\hline 6 & 17.22 & 1047 & Trans-ocimene & 3.86 \\
\hline 7 & 19.06 & 1084 & Terpinene & 0.08 \\
\hline 8 & 19.70 & 1096 & Linalool & 0.157 \\
\hline 9 & 21.16 & 1126 & Ocimene (allo) & 0.16 \\
\hline 10 & 25.26 & 1226 & Methyl chavicol & 84.83 \\
\hline 11 & 28.06 & 1270 & Geranial & 0.17 \\
\hline 12 & 28.66 & 1283 & Iso bornyl acetate & 0.1 \\
\hline 13 & 31.80 & 1353 & Eugenol & 0.12 \\
\hline 14 & 32.87 & 1377 & Iso safrole (E) & 0.37 \\
\hline 15 & 33.85 & 1399 & Methyl eugenol & 0.07 \\
\hline 16 & 37.65 & 1491 & Valencene & 0.1 \\
\hline 17 & 38.84 & 1520 & $\beta$-sesquiphellandrene & 0.07 \\
\hline 18 & 40.43 & 1561 & Cinnamaldehyde (para-methoxy) & 0.2 \\
\hline 19 & 40.95 & 1574 & Spathulenol & 0.09 \\
\hline- & - & - & Monoterpenes & 10.087 \\
\hline- & - & - & Oxygenated monoterpenes & 85.817 \\
\hline- & - & - & Sesquiterpenes & 0.17 \\
\hline- & - & - & Oxygenated sesquiterpenes & 0.29 \\
\hline Total & - & - & - & 96.364 \\
\hline
\end{tabular}

In this study the total phenolic content and antioxidant activity was investigated and was compared with syntial oil inhibited oxidation of linoleic acid in a manner thetic antioxidant BHT. We showed that Tarragon essen-

Table 2. Total Phenolic Content, Antioxidant Capacity of A. dracunculusEssential Oil

\begin{tabular}{lll}
\hline & Total Phenolic Content, $\mathbf{m g ~ G A E s}^{\mathrm{a}} / \mathbf{g r}$ & Antioxidant Capacity $^{-}$ \\
\hline Artemisia dracunculusEssential oil & $10.16 \pm 0.08$ & $50 \pm 1.63$ \\
BHT $^{\mathrm{a}}$ & - & $90.6 \pm 3.30$ \\
\hline
\end{tabular}

${ }^{\mathrm{a}}$ Abbreviations: GAEs, gallic Acid Equivalents; BHT, butylated hydroxytoluene

Also the essential oil showed different degrees of inhibi- $\quad$ tory effect on the growth of tested bacterial strains (Table 3). 
Sharafati Chaleshtori Ret al.

\begin{tabular}{llllllll}
\hline Table 3. Antibacterial Activity of A. dracunculus Essential Oil \\
\hline & $\begin{array}{l}\text { Staphylococcus } \\
\text { aureus }\end{array}$ & $\begin{array}{l}\text { Listeria mono- } \\
\text { cytogenes }\end{array}$ & $\begin{array}{l}\text { Alcaligenes } \\
\text { faecalis }\end{array}$ & $\begin{array}{l}\text { Providencia } \\
\text { rettgeri }\end{array}$ & $\begin{array}{l}\text { Serratia } \\
\text { marcescens }\end{array}$ & $\begin{array}{l}\text { Shigella } \\
\text { dysenteriae }\end{array}$ & $\begin{array}{l}\text { Klebsiella } \\
\text { oxytoca }\end{array}$ \\
\hline MIC $^{\text {a }}, \mathbf{m g} / \mathbf{m L}$ & 62.4 & 15.6 & 15.6 & 31.2 & 3.8 & 3.8 & 7.8 \\
MBC $^{\text {a }}, \mathbf{m g} / \mathbf{m L}$ & 250 & 250 & 31.2 & 62.4 & 7.8 & 7.8 & 62.4 \\
\hline
\end{tabular}

${ }^{a}$ Abbreviations: MIC, minimum inhibitory concentration; $M B C$, minimum bactericidal concentration

\section{Discussion}

In a similar study conducted in Turkey, the main compounds in A. dracunculus essential oil were (Z)-anethole (81.0\%), z- $\beta$-ocimene (6.5\%), (E)- $\beta$-ocimene (3.1\%), limonene (3.1\%) and methyleugenol (1.8\%) (6). Also, Ayoughi et al. reported that the predominant compounds in A. dracunculus essential oil were (Z)-anethole (51.72\%), z- $\beta$-ocimene (8.32\%), methyleugenol (8.06\%), limonene (4.94\%) and linalool (4.41\%) (2). In the present work, the major compound was methyl chavicol which is a double-bond isomer of anethole. However, in our results methyleugenol $(0.07 \%)$ was much lower than that of the above studies. The different chemical compositions of the essential oils might be related to harvest time, geographical situation, ground conditions and genetic factors $(13,14)$.

It has been shown that there is a correlation between antioxidant capacity and antibacterial activity as well as the total phenolic content of the herb extracts or essential oils $(9,15)$. Furthermore, it has been reported that oxygenated monoterpenes have antioxidant and antimicrobial activities (2). We showed that Tarragon essential oil had antioxidant activity and inhibited oxidation of linoleic acid in a manner less than BHT (Table 2). This can be due to high level of methyl chavicols such as the oxygenated monoterpenes and the total phenolic content. Other reports have demonstrated that linalool, limonene, spathulenol and eugenol have antioxidant activities $(2,16)$.

The essential oil showed different degrees of inhibitory effect on the growth of tested bacterial strains (Table 3 ). The Gram negative bacteria especially $S$. marcescens and Sh. dysenteriae were the most sensitive, while L. monocytogenes and S. aureus (Gram positive) were the most resistant bacteria against this essential oil. Previous studies reported antibacterial activity of Tarragon EO against $E$. coli , S. aureus ( 17 ), Salmonella typhimurium, L. monocytogenes, Yersinia enterocolitica and Bacillus cereus (18). Its results revealed that E. coli (17) and Y. enterocolitica (18) were more sensitive than other bacteria. Raeisi et al. showed that S. aureus had more sensitivity than E. coli to Tarragon EO (19). However, some studies have reported that Gram negative bacteria are more resistant than Gram positives, due to restricted diffusion of the hydrophobic compounds through the hydrophilic cell wall structure, such as lipo-polysaccharide (LPS) $(20,21)$.

Kordali et al. exhibited that the essential oil of A. dra- cunculus with a high level of (Z)-anethole (81\%) did not have any effect on $S$. aureus (6). The results of the present study showed that $A$. dracunculus essential oil with high level of methyl chavicol (84.83\%) had antibacterial activity against $S$. aureus. The antibacterial activity of the essential oil is dependent upon its major compounds. However some researchers reported higher antibacterial activity of the whole essence than major compounds blended in essence due to antibacterial properties of minor compounds in essential oil $(16,22)$.

Based on the results of this study, the essence of Tarragon had biological properties as anti-oxidative and antibacterial activities. Also, the major aromatic compound was methyl chavicol. The compounds in the essence may be helpful for prevention of cancer and atherosclerosis, which is related to the inhibition of lipid oxidation. Eventually, it is recommended to perform surveys on this essential oil and prove it as a natural preservative in food models in order to replace synthetic preservatives in foods.

\section{Acknowledgements}

The authors are grateful to the personnel of Medical Plants Research Center in Shahre-Kord University of Medical Sciences, Iran.

\section{Authors' Contribution}

Reza Sharafati-Chaleshtori and Noordahr Rokni: developed the original idea and the protocol, abstracted and wrote the manuscript. Reza Sharafati-Chaleshtori, Noordahr Rokni, Vadood Razavilar and Mahmoud RafieianKopaei contributed to the development of the protocol, abstracted data, and prepared the manuscript.

\section{Financial Disclosure}

Authors declare that there are not any relevant financial interests related to the material in the manuscript

\section{Funding/Support}

This study was part of a Ph.D. thesis supported by Science and Research branch, Islamic Azad University, Tehran.

\section{Role of the Sponsor}

The funding organizations are public institutions and 
had no role in the design and conduct of the study collection, management, and analysis of the data; or preparation, review, and approval of the manuscript. The Medical Plants Research Center, Shahre-Kord University of Medical Sciences, Shahre-Kord, IR Iran, provided practical support for the survey processes.

\section{References}

1. Guimarães R, Sousa MJ, Ferreira ICFR. Contribution of essential oils and phenolics to the antioxidant properties of aromatic plants. Ind Crops Prod. 2010;32(2):152-156.

2. Ayoughi F, Marzegar M, Sahari MA, Naghdibadi H. Chemical compositions of essential oils of Artemisia dracunculus L. and endemic Matricaria chamomilla L. and an evaluation of their antioxidative effects. J Agr Sci Tech. 2011;13(1):79-88.

3. Hajlaoui H, Snoussi M, Noumi E, Zanetti S, Ksouri R, Bakhrouf A. Chemical composition, antioxidant and antibacterial activities of the essential oils of five Tunisian aromatic plants. Ital J Food Sci.2010;22(3).

4. Sengul M, Ercisli S, Yildiz H, Gungor N, Kavaz A, Çetin B. Antioxidant, antimicrobial activity and total phenolic content within the aerial parts of Artemisia absinthum, Artemisia santonicum and Saponaria officinalis. Iran J Pharm Res. 2010.

5. Jazani NH, Zartoshti M, Babazadeh H, Ali-daiee N. Antibacterial Effects of Artemisia dracunculus Essential Oil on Multidrug Resistant Isolates of Acinetobacter baumannii. Bacteriol J. 2011;1(1):31-36.

6. Kordali S, Kotan R, Mavi A, Cakir A, Ala A, Yildirim A. Determination of the chemical composition and antioxidant activity of the essential oil of Artemisia dracunculus and of the antifungal and antibacterial activities of Turkish Artemisia absinthium, A. dracunculus, Artemisia santonicum, and Artemisia spicigera essential oils. J Agric Food Chem. 2005;53(24):9452-8.

7. Busatta C, Vidal RS, Popiolski AS, Mossi AJ, Dariva C, Rodrigues MR, et al. Application of Origanum majorana L. essential oil as an antimicrobial agent in sausage. Food Microbiol. 2008;25(1):207-11.

8. Adams RP. Identification of essential oil components by gas chromatography/mass spectroscopy. 2 ed: Allured Publishing Corporation, Carol Stream, Illinois; 2001.

9. Sharafati-Chaleshtori R, Sharafati-Chaleshtori F, Rafieian M. Biological characterization of Iranian walnut (Juglans regia) leaves. Turk JBiol. 2011;35:635-9.

10. Shirzad H, Taji F, Rafieian-Kopaei M. Correlation between anti- oxidant activity of garlic extracts and WEHI-164 fibrosarcoma tumor growth in BALB/c mice. J Med Food. 2011;14(9):969-74.

11. Isenberg HD. Clinical Microbiology Procedures Handbook. 2 ed. Washington, DC:ASM Press; 2004.

12. Quave CL, Plano LR, Pantuso T, Bennett BC. Effects of extracts from Italian medicinal plants on planktonic growth, biofilm formation and adherence of methicillin-resistant Staphylococcus aureus. J Ethnopharmacol. 2008;118(3):418-28.

13. Goze I, Alim A, Tepe AS, Sokmen M, Sevgi K, Tepe B. Screening of the antioxidant activity of essential oil and various extracts of Origanum rotundifolium Boiss from Turkey. J Med Plants Res. 2009;3:246-254.

14. Damjanovic-Vratnica B, Perovic A, Sukovic D, Perovic S. Effect of vegetation cycle on chemical content and antibacterial activity of Satureja montana L. Arch Biol Sci. 2011;63(4):1173-1179.

15. Albayrak S, Aksoy A, Sagdic O, Budak U. Phenolic compounds, antioxidant and antimicrobial properties of Helichrysum species collected from Eastern Anatolia, Turkey. Turk J Biol. 2010;34(4):463-473.

16. Kirchner K, Wisniewski Jr A, Cruz AB, Biavatti MW, Netz DJA. Chemical composition and antimicrobial activity of Hedyosmum brasiliense Miq., Chloranthaceae, essential oil. Revis Bras Farmacogn. 2010;20(5):692-699.

17. Bonyadian M, Karim G. Study of the effects of some volatile oils of herbs against Escherichia coli and Staphylococcus aureus in broth media. J Fac Vet Med Univ Tehran. 2002;57:81-3.

18. Bonyadian M, Moshtaghi H. Bacteriocidal Activity of Some Plants Essential Oils Against Bacillus cereus,Salmonella typhimurium, Listeria monocytogenes and Yersinia enterocolitica. Res J Microbiol. 2008;3(11):648-653.

19. Raeisi M, Tajik H, Razavi RS, Maham M, Moradi M, Hajimohammadi B, et al. Essential oil of tarragon (Artemisia dracunculus) antibacterial activity on Staphylococcus aureus and Escherichia coli in culture media and Iranian white cheese. Iran J Microbiol. 2012;4(1):30-4.

20. Amensour M, Bouhdid S, Fernández-López J, Idaomar M, Senhaji NS, Abrini J. Antibacterial Activity of Extracts ofMyrtus communisAgainst Food-Borne Pathogenic and Spoilage Bacteria. Int $J$ Food Prop. 2010;13(6):1215-1224.

21. Sulaimain S, Ibrahim D, Kassim J, Sheh-Hong L. Antimicrobial and antioxidant activities of condensed tannin from Rhizophora apiculata barks. J Chem Pharmaceut Res. 2011;3(4):436-44.

22. Gulfraz M, Mehmood S, Minhas N, Jabeen N, Kausar R, Jabeen K, et al. Composition and antimicrobial properties of essential oil of Foeniculum vulgare. Afr J Biotechnol. 2008;7:4364-8. 